\title{
ANALISA PERKEMBANGAN PERATURAN DAN PENERAPAN AKUNTANSI SYARIAH DI INDONESIA
}

\author{
Widiana \\ Fakultas Hukum \\ Universitas Padjadjaran \\ widiana1108@gmail.com
}

\begin{abstract}
1 period of about 24 weeks, the sharia economic systems has been initiated in Indonesia. Assessment of sharia economic system continues to be done and this also affects the sharia accounting that continues to be developed as a financial recorder in sharia financial institutions from 1991. it started since the founding of Bank Mumalat whose the design had been studied long before its establishment. Subsequently issued legislation governing the legality of sharia economics and accounting. In order to accelerate the development, the government amend the sharia legislation several times and conduct an assessment of sharia accounting so that it is published PSAK Sharia, Accounting Guidelines for Indonesian Sharia Banking (PAPSI), and the MUI fatwa as the basis used in sharia accounting.
\end{abstract}

Keywords: Sharia Accounting, Islamic Economy, PSAK Sharia, PAPSI

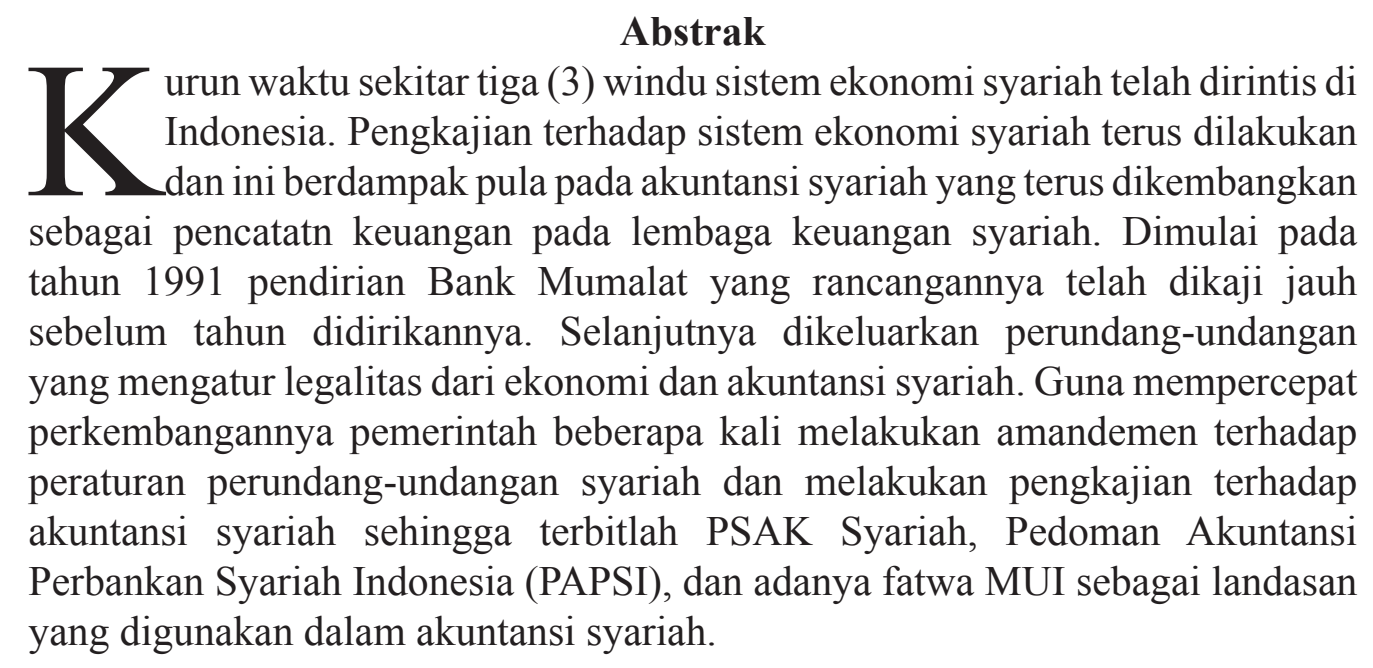

Kata kunci: Akuntansi Syariah, Ekonomi Islam, PSAK Syariah, PAPSI

\section{PENDAHULUAN}

Perkembangan akuntansi syariah belakangan ini semakin meluas tidak hanya di Indonesia melainkan di seluruh dunia juga mengalami hal yang sama. Hal ini disebabkan adanya perkembangan dari sistem keuangan islam yang sangat pesat. Peraturan syariah pun mulai disusun untuk menunjang perkembangan akuntansi agar memiliki kedudukan yang jelas dalam suatu negara. di Indonesia sudah beberapa kali mengadakan perubahan terhadap peraturan akuntansi syariah sehingga ada sedikit penyesuain yang dilakukan pada penerapan akuntansi syariah yang ada di Indonesia.

Meskipun telah berdiri selama 20 tahun, sistem keuangan Islam (Islamic Financing System/ IFS) masih memiliki market share yang sangat kecil. Pada tahun 2009 besarnya aset perbankan 
syariah dibandingkan dengan total aset perbankan nasional sebesar 2,45\%. Hingga November 2011, sistem keuangan Islam hanya memiliki market share 3,82\%. Dengan demikian, pertumbuhan sistem keuangan Islam selama 2009 sampai dengan 2011 hanya 1,37\% atau 0,5\% per tahun. Dengan tingkat pertumbuhan dan ukuran market share yang sangat kecil ini tentunya pengaruh sistem keuangan Islam tidak akan berdampak luas pada perekonomian Indonesia. Sistem keuangan Islam memiliki beberapa keunggulan dibandingkan dengan sistem keuangan konvensional (Conventional Financing System/ CFS). Fungsi intermediasi perbankan syariah yang tinggi, ditunjukkan dengan tingkat FDR rata-rata diatas $90 \%$ bahkan pernah lebih dari $100 \%$. Tercatat komposisi aset yang didominasi pembiayaan kepada sektor riil terutama sektor usaha kecil dan menengah dengan rasio FDR mencapai 103,64\% pada tahun 2008. Data November 2011 mencatat tingkat FDR perbankan syariah sebesar 91,41\%. Meskipun tingkat FDR perbankan syariah akhirakhir ini berada di bawah 100\%, namun lebih unggul apabila dibandingkan dengan perbankan konvensional yang hanya mencapai $81 \%$ (November 2011). Hal ini membuktikan bahwa dana yang disimpan pada perbankan syariah sebagian besar disalurkan sebagai penggerak pada sektor riil khususnya sektor usaha kecil dan menengah. Namun keunggulan sistem keuangan Islam belum secara signifikan berdampak pada perekonomian Indonesia. Hal ini disebabkan ukuran sistem keuangan Islam masih sangat kecil dan lebih dominannya sistem keuangan konvensional di Negara ini.

Hadirnya akuntansi dalam bentuk standar akuntansi keuangan sebagai formula praktek atau aplikasi lapangan, dipengaruhi oleh prinsip - prinsip ekonomi yang dianut yang melandasi kegiatan berekonomi. Bahwa sekali lagi bentuk akuntansi sarat dipengaruhi situasi objektif (seperti lingkungan, sosial, budaya, ekonomi, politik, dan lain-lain) yang dianut suatu negara. Sebab jika akuntansi dianggap sebagai teknologi, maka ia adalah merupakan „,bentukan ${ }^{\text {ee }}$ yang dipergunakan untuk kepentingan tujuan tertentu. Lain hal yang bersifat substansial, ia tidak dipengaruhi dimensi ruang dan waktu, tetapi bentuk itu sendiri sangat terpengaruh oleh ruang dan waktu. Wajarlah dengan demikian, bentuk-bentuk yang terepresentasikan dalam standar akuntansi keuangan masing-masing negara menjadi beragam dan boleh jadi tidak ada persamaan baik secara bentuk maupun substansial.

Menjamurnya berbagai lembaga keuangan syariah telah mendorong tumbuhnya harapan yang begitu besar. Bukan saja harapan bahwa lembaga keuangan syariah dapat menawarkan produk dan jasa yang sesuai syariah, bahkan juga muncul harapan para pelaku yang bekerja di lembaga tersebut benar-benar menjalankan nilai-nilai Islami yang begitu luhur. Perkembangan lembaga keuangan syariah yang menggembirakan ini sayangnya menghadapi berbagai kendala atau masalah. Salah satunya kendalanya yaitu terbatasnya Sumber Daya Manusia (SDM) yang berbasis syariah. Perlu diketahui majunya sebuah lembaga keuangan syariah tidak hanya dari pertumbuhan yang spektakuler dengan penyebaran informasi yang baik, tetapi harus didukung dengan para pekerja yang mempunyai kemampuan di bidang syariah. Tak hanya perkembangan yang pesat dari segi lembaga keuangan syariah saja namun kinerja perusahaan tiap lembaga keuangan syariah juga diperlukan untuk menentukan apakah perusahaan mencapai tingkat profitabilitas dan perkembangan usahanya serta kinerja manajemen, hal ini dapat dilihat dari laporan keuangan yang disajikan pada akhir periode usaha yang kemudian diadakan suatu analisis atas laporan keuangan tersebut.

\section{LATAR BELAKANG}

Kejadian ekonomi yang ada di Indonesia sangat baik untuk dijadikan sejarah agar bisa diambil pelajaran dari hal tersebut. Karena bagaimanapun juga sejarah dapat mengajarkan kita agar tidak masuk ke dalam lubang yang sama dan agar kita bisa maju demi pengembangan ekonomi Indonesia yang lebih baik. Di saat sekarang ini Indonesia tengah menggencarkan implementasi akuntansi syariah untuk pemenuhan kebutuhan sistem ekonomi islam yang tengah dilakukan di Indonesia. Beberapa peraturan akuntansi syariah disusun agar lembaga keuangan dapat menyesuaikan 
pencatatan yang seharusnya dilakukan jika lembaga keuangan menggunakan sistem syariah. Tujuan dari kepenulisan ini agar kita bisa mengetahui secara lebih jelas mengenai perkembangan yang terjadi terhadap akuntansi syariah mulai dari peraturan dan penerapnnya.

Peraturan ini beberapa kali juga mengalami perubahan sejak mulai diterapkan akuntansi syariah sampai pada saat ini. Hal ini disebabkan perkembangan ilmu pengetahuan berdasarkan pengkajian ilmu syariah yang telah dilakukan. Akuntansi syariah pada mulanya memang diterapkan pada lembaga keuangan perbankan syariah tetapi untuk sekarang ini lembaga keuangan yang lainnya juga telah menggunakan akuntansi syariah dengan berpedoman pada peraturan yang dikeluarkan oleh pemerintah.

Komite Terminologi AICPA (The Committe on Terminology of The American Institute of Certified Public Accountants) mendefinisikan akuntansi adalah seni pencatatan, penggolongan dan peringkaan transaksi dan kejadian yang bersifat keuangan dengan cara yang berdayaguna dan dalam bentuk satuan uang, dan pengintrepetasian hasil proses tersebut. Yang terbaru akuntansi telah didefinisikan dengan mengacu pada konsep informasi kuantitatif, akuntansi adalah aktivitas jasa. Fungsinya adalah menyediakan informasi kuantitatif terutama yang bersifat keuangan tentang entitas ekonomik yang diperkirakan bermanfaat dalam pembuatan keputusan-keputusan ekonomis dalam membuat pilihan diantara alternatif tindakan yang ada. Akuntansi syariah yang berhubungan dengan pengakuan dan pencatatan transaksi dan pengungkapan ha-hak dan kewajiban secara adil. ${ }^{1}$

Allah berfirman :

"Hai orang-orang yang beriman, apabila kamu bermuamalah tidak secara tunai untuk waktu yang ditentukan hendaklah kamu menuliskannya. Dan hendaklah seorang penulis diantara kamu menuliskannya dengan benar" (QS. Al Baqarah :282.

Tujuan laporan keuangan syariah adalah untuk menyediakan informasi yang menyangkut posisi keuangan, kinerja serta perubahan posisi keuangan suatu entitas syariah yang bermanfaat bagi sejumlah besar pemakai dalam pengambilan keputusan ekonomi, tujuan lainnya adalah: (1) Meningkatkan kepatuhan terhadap prinsip syariah dalam setiap transaksi dan kegiatan usaha. (2) Informasi kepatuhan entitas syariah terhadap prinsip syariah serta informasi asset, kewajiban, pendapatan dan beban yang tidak sesuai dengan prinsip syariah bila ada yang dalam perolehan dan penggunaannya. (3) Informasi untuk membantu mengevaluasi pemenuhan tanggung jawab entitas dan syariah terhadap amanah dalam mengamankan dana, menginvestasikannya pada tingkat keuntungan yang layak. (4) Informasi mengenai keuntungan investasi yang diperoleh penanam modal dan pemilik dana syirkah temporer dan informasi mengenai pemenuhan kewajiban. (obligation) fungsi sosial entitas syariah. Termasuk pengelolaan dan penyaluran zakat, infak, sedekah dan wakaf.

Tujuan diterapkannya akuntansi syariah adalah untuk mencapai keadilan sosial-ekonomi, dan sebagai bentuk menjalankan ibadah kita dalam memenuhi kewajiban kepada Allah SWT, sebagai bentuk pertanggungjawaban kita terhadap tugas individu dalam melaporkan segala hal yang berkaitan dengan laporan keuangan. Hasil akhir teknik akuntansi syariah berupa informasi akuntansi yang akurat untuk menghitung zakat dan pertanggungjawaban secara horizontal kepada Allah SWT dengan berlandaskan moral, iman, taqwa serta vertikal kepada para pemegang saham (Stakeholder).

Dua sumber utama konsep ekonomi syariah berporos pada Al Qur'an dan Al Hadist. Ironisnya, kedua hukum Islam tersebut tidak pernah benar-benar digunakan sebagai landasan dalam merumuskan konsep epistemologis ekonomi Islam itu sendiri melainkan fiqh yang "sekedar" rasionalisasi kreatif ulama yang dijadikan sebagai acuan utamanya. Oleh karenanya, ekonomi Islam banyak mengadopsi begitu saja teori-teori yang ada dalam ekonomi konvensional dengan melakukan penyesuaian atau dipaksakan dengan melakukan sedikit penyesuaian atau 1 Wiroso, Akuntansi Transaksi Syariah, Jakarta : Ikatan Akuntan Indonesia,.2011, h-15 
dipaksakan agar sesuai dengan ayat atau hadis tertentu. Jika memang ada ayat atau hadis yang dijadikan sebagai suatu landasan syariah bagi suatu model transaksi ekonomi syariah, pengaturan yang berbasis sistematis dan kritis yang memenuhi prinsip-prinsip interpretasi yang valid tidak dilakukan terlebih dahulu.

\section{RUMUSAN MASALAH}

Berdasarkan uraian dari latar belakang diatas, maka penulis mendalami permasalahan mengenai bagaimana histori perkembangan peraturan akuntansi syariah di Indonesia? dan bagaimana perkembangan sistem penerapan akuntansi syariah di Indonesia?

\section{PEMBAHASAN}

\section{Periode Awal (Tahun 1991 - 1998)}

a. Peristiwa Ekonomi yang Terjadi di Indonesia

Pada masa ini Indonesia banyak mengalami keguncangan dalam perekonomian. Hal ini dikarenakan terjadi krisis berkepanjangan yang terjadi di Indonesia. Sehingga inflasi meningkat begitu tajam. Hal ini juga diperparah dengan adanya permasalahan politik terkait penumbangan rezim Soeharto yang semakin memperburuk kondisi ekonomi Indonesia. Sehingga bisa dikatakan kondisi ekonomi dan politik di Indonesia sedang tidak stabil pada periode ini. Nilai rupiah semakin merosot yang semula Rp 2.300 per dollar AS (pertengahan 1997) menjadi Rp 17.000 per dollar AS (Januari 1998). Hutang negara yang menumpuk juga menjadi daftar hitam ditengah pergolakan ekonomi. Dampak yang ditimbulkan begitu meluas, terjadi kerusuhan dan kekerasan di beberapa kota yang dilakukan secara massal sehingga pelaku kejahatan yang tidak bisa lagi terdeteksi, kejadian ini dikenal dengan peristiwa Mei 1998. Dari semua kejadian ini berimbas pada melambungnya harga bahan pokok, kemiskinan meningkat, terjadi bencana kelaparan dan angka putus sekolah tinggi. Pada akhirnya masa orde baru pun runtuh yang diganti dengan masa reformasi.

Kejadian ini juga berakibat nasabah dan investor luar negeri tidak mempercayai Lembaga Keuangan Bank sehingga terjadi penarikan uang secara besar-besaran yang berdampak terjadinya negative spread pada Bank Konvensional yang memang menggunakan sistem bunga. Akan tetapi, Perbankan Syariah masih bisa bertahan menghadapi situasi ekonomi pada periode ini dikarenakan sistem bagi hasil yang digunakan oleh Bank Syariah tidak mewajibkan Bank Syariah membagi hasil (profit sharing) kepada investor ketika uang yang disimpan tidak digunakan sebagai modal oleh peminjam. Setiap transaksi pada Bank syariah juga berlandaskan pada aset dasar (underlying asset) sehingga konsep berhati-hati sangat dipegang oleh Bank Syariah. Hal ini berbanding terbalik dengan konsep bunga pada Bank Konvensional yang wajib membayar bunga investor walaupun kondisi ekonomi sedang dilanda krisis selain itu Bank Konvensional melakukan tansaksi yang bersifat spekulatif.

b. Peraturan yang Dikeluarkan Terkait dengan Akuntansi Syariah

Kejadian ekonomi di Indonesia tetap berlangsung bersamaan dengan terjadinya krisis ekonomi. Pemerintah mulai memperhatikan adanya peraturan mengenai Perbankan Syariah. hal ini dengan disahkannya Undang-undang Perbankan Nomor 7 Tahun 1992 tentang Perbankan memberikan peluang untuk membuka bank yang beroperasi dengan prinsip bagi hasil ${ }^{2}$ dan mengatur dual banking system, yaitu sistem bank syariah penerapannya berdampingan dengan sistem bank konvensional ${ }^{3}$ bersama-sama

\footnotetext{
2 Bank Indonesia, 2007, “Cetak Biru Pengembangan Perbankan Syariah Indonesia”, http://www.bi.go.id/id/ publikasi/lain/lainnya/pages/blue\%20print.aspx, diunduh Febuari 2016

3 Ridzki Muhammad Rhamdan, 2009, “Akuntansi Syariah Sebagai Kontruksi Sosial”, http://agt122005.blogspot.
} 
mendukung pembangunan perekonomian Nasional. Pada tahun 1992 juga terbentuk suatu Lembaga Keuangan Bank berbasis syariah yaitu Bank Muamalat.

Pada tahun 1998 diterbitkan buku Accounting Auditing Standard For Islamic Financial Institution dikeluarkan oleh Accounting And Auditing Organization For Islamic Financial Institution yang merupakan suatu badan usaha nirlaba yang otonom. ${ }^{4}$ Pada tahun ini diterbitkan Undang-undang Nomor 10 tahun 1998 yang merupakan amandemen dari UU No.7/1992 tentang Perbankan, memberikan landasan hukum yang lebih kuat bagi keberadaan bank yang melakukan kegiatan usaha berdasarkan prinsip syariah. Bank konvensional dimungkinkan untuk membuka unit usaha syariah. ${ }^{5}$ Bank Indonesia juga sebagai pemrakarsa, membentuk tim penyusunan PSAK Bank Syariah yang meliputi Bank Indonesia, Ikatan Akuntansi Indonesia, Bank Muamalat Indonesia dan Departemmen Keuangan.

c. Penerapan Akuntansi Syariah

Pada tanggal 24 Rabius Tsani 1412 atau 1 November 1991 didirikan PT. Bnak Muamalat Indonesia tbk yang diprakasai oleh Majelis Ulama Indonesia (MUI) dan pemerintah Indonesia dan Memulai kegiatan operasinya pada 27 syawal 1412 atau 1 Mei 1992. ${ }^{6}$ Sampai dengan tahun 2002 belum ada PSAK syariah yang mengatur sehingga pada periode ini masih mengacu pada PSAK 31 tentang Akuntansi Perbankan walaupun tidak dapat dipergunakan sepenuhnya terutama paragraf-paragraf yang bertentangan dengan prinsip syariah seperti perlakuan akuntansi untuk kredit. ${ }^{7}$ Sehingga bisa dikatakan pada periode ini bentuk nyata implementasi Akuntansi Syariah masih belum diakomodasi oleh pemerintah. Hal ini dikarenakan pemerintah harus melakukan pengkajian terlebih dahulu pada sistem Akuntansi yang akan di implementasikan pada Perbankan yang ada di Indonesia.

d. Dampak dari Peraturan dan Penerapan Akuntansi Syariah

Dampak yang terjadi adalah Indonesia sudah selangkah lebih maju dalam aspek perekonomian. Indonesia yang berpenduduk muslim terbanyak di seluruh dunia pada akhirnya berani memulai langkah dalam perekonomian syariah. Negara Malaysia dengan jumlah penduduk muslim seperdelapan dari jumlah penduduk muslim Indonesia sembilan tahun lebih dulu mengimplementasikan akuntansi syariah di negaranya. Dari langkah awal ini maka nantinya akan berkembang lebih lanjut mengenai pengkajian akuntansi syariah yang akan digunakan di Indonesia.

\section{Masa Pertengahan (Tahun 2000-2007)}

a. Peristiwa Ekonomi yang Terjadi di Indonesia

Pada tahun 1999 aktivitas ekonomi perlahan mengalami pemulihan yang ditunjukkan oleh pertumbuhan ekonomi sebesar 0,8\%. Pada tahun 2000 tingkat pertumbuhan mencapai titik 4,7\% yang menunjukkan peningkatan cukup signifikan dari tahun sebelumnya. Tingkat pertumbuhan ekonomi di Indonesia meningkat pada tahun 2002 4,50\% dan ditahun $20076,35 \%$ sehingga terjadi peningkatan sebesar 1,85\%. Ini bisa dimaknai dengan membaiknya kondisi perekonomian Indonesia. ${ }^{8}$

com/2007/08/akuntansi-syariah 15.html, diunduh Desember 2016

4 Wiroso, Akuntansi Transaksi Syariah, Jakarta: Ikatan Akuntan Indonesia,.2011, h-17

5 Bank Indonesia, 2007, "Cetak Biru Pengembangan Perbankan Syariah Indonesia”, http://www.bi.go.id/id/ publikasi/lain/lainnya/pages/blue\%20print.aspx, diunduh Febuari 2016

6 PTBank Muamalat Indonesia tbk, "Tentang Muamalat”, http://www.bankmuamalat.co.id/profil-bank-muamalat, diunduh Januari 2017

7 Sri Nurhayati, Wasilah, (dalam Wiroso 2011), Akuntansi Syariah Di Indonesia Edisi 4, Jakarta : Salemba Empat,. 2015, h-9

8 Sutiono, 2015, "Profil Perekonomian Indonesia" http://www.bppk.kemenkeu.go.id/publikasi/artikel/150-artikel- 
b. Peraturan yang Dikeluarkan Terkait dengan Akuntansi Syariah

Pada Maret 2000 Tim Penyusun PSAK telah membuahkan hasil yaitu diterbitkannya Exposure Draft Kerangka Dasar Penyusunan Laporan Keuangan Syariah dan Exposure Draft tentang PSAK No. 59 tentang Akuntansi Perbankan Syariah. Setelah Dewan Syariah memberikan opini bahwa PSAK No. 59 tentang Akuntansi Perbankan Syariah tidak bertentangan dengan aspek syariah maka PSAK No. 59 tentang Akuntansi Perbankan Syariah disahkan pada tanggal 1 Mei 2002 dan secara efektif mulai berlaku tanggal 1 Januari 2003. ${ }^{9}$ Undang-undang No.23/1999 yang selanjutnya diamandemen dengan Undang-undang No.3/2004 tentang Bank Indonesia, memberi kewenangan kepada BI sebagai otoritas pengawasan perbankan syariah, dan memungkinkan BI untuk dapat menggunakan instrumen kebijakan moneter berdasarkan prinsip syariah. ${ }^{10}$

c. Penerapan Akuntansi Syariah

Periode tahun 2002-2007 sudah ada PSAK 59 tentang Akuntansi Perbankan Syariah yang dapat digunakan sebagai acuan akuntansi untuk Bank Umum Syariah, Bank Perkreditan Rakyat Syariah dan kantor cabang syariah sebagaimana tercantum dalam ruang lingkup PSAK tersebut. ${ }^{11}$ Akan tetapi PSAK 59 hanya diperuntukan Lembaga Keuangan Bank sedangkan Lembaga Keuangan non-Bank tidak terikat pada PSAK 59.

d. Dampak dari Peraturan dan Penerapan Akuntansi Syariah

Dampak dari adanya amandemen perundang-undangan ini yaitu semakin memerikan peluang bagi berkembangnya sistem akuntansi syariah di Indonesia. Karena sudah ada acuan tetap yang dapat digunakan dan dapat dipertanggungjawabkan oleh perbankan syariah. Karena bagaimanapun juga sistem syariah tidak bisa disamakan dengan sistem konvensional sehingga menjadi sangat penting peraturan yang independen dalam sistem akuntansi syariah. Akan tetapi pengembangan dalam pengkajian sistem akuntansi syariah non-bank harus dilakukan agar bisa mengakomodir seluruh lini dari sistem lembanga keuangan syariah.

\section{Masa Sekarang (Tahun 2008-sekarang)}

a. Peristiwa Ekonomi yang Terjadi di Indonesia

Pada dasarnya akuntansi syariah mengakui pendapat logis universal sesuai dengan hakekat kebenaran yang bersumber Al Qur'an dan As Sunnah, dimana akuntabilitas proses binis dan hasil bisnis dari aktivitas ekonomi secara penuh nilai adil untuk kemakmuran umat manusia. Hal tersebut menunjukkan bahwa akuntansi syariah tidak berbasis faham kapitalis dan sosialis. Akuntansi syariah memiliki tantangan dan kendala. Secara implikatif tantangan pada formulasi formal atau standar, dalam persamaan akuntansi dan laporan keuangan masih berkutat pada bagaimana aset sebagai aktiva sama dengan pasiva yang murni tanpa melibatkan bunga ataupun uang yang bersifat diperdagangkan. Sedangakan kendala, dikarenakan di negara yang bersangkutan, seperti di Indonesia masih melibatkan lembaga-lembaga keuangan yang masih menggunakan sistem bunga dan nilai perdagangan uang dalam berbagai bentuknya. ${ }^{12}$

keuangan-umum/21178-profil-perekonomian-indonesia

9 Wiroso, Akuntansi Transaksi Syariah, Jakarta : Ikatan Akuntan Indonesia,.2011, h-17

10 Bank Indonesia, 2007, "Cetak Biru Pengembangan Perbankan Syariah Indonesia”, http://www.bi.go.id/id/ publikasi/lain/lainnya/pages/blue\%20print.aspx, diunduh Febuari 2016

11 Sri Nurhayati, Wasilah, (dalam Wiroso 2011), Akuntansi Syariah Di Indonesia Edisi 4, Jakarta : Salemba Empat,. 2015, h-9

12 Susana Himawati dan Agung Subono, “Praktik Akuntansi Dan Perkembangan Akuntansi Syariah di Indonesia”. Sosial Budaya, 2 (2),ISSN 1979-6889, 2009, h.4 
b. Peraturan yang Dikeluarkan Terkait dengan Akuntansi Syariah

Pada tanggal 16 Juli 2008 diterbitkan Undang-Undang No.21 tahun 2008, sehingga perbankan syariah di Indonesia semakin memiliki landasan hukum memadai yang akan mendorong perkembangan perbankan syariah lebih cepat. ${ }^{13}$ PSAK 59 hanya diperuntukkan bagi Perbankan Syariah saja sedangkan disisi yang lain Lembaga Keuangan Syariah nonBank telah berkembang maka Dewan Standar Akuntansi Keuangan-Ikatan Akuntansi Indonesia (DSAK-IAI) membentuk Komite Akuntansi Syariah (KAS) agar dapat menyusun penerbitan PSAK Syariah yang akan digunakan oleh semua entitas syariah. Mulai tahun buku 2008 DSAK-IAI mengesahkan PSAK Syariah yaitu PSAK 101 sampai dengan PSAK 106 dan Kerangka Dasar Penyususnan Dan Penyajian Lembaga Keuangan Syariah (KDPPLKS) yang terpisah dengan PSAK dan Kerangka Dasar Akuntansi NonSyariah. Pada periode ini terbit PSAK Syariah lain (Exposure Draft) yang diharapkan dapat dilaksanakan mulai tahun buku 2009. ${ }^{14}$

Sebagai langkah konkrit dari Bank Indonesia untuk pengembangan perbankan syariah maka Bank Indonesia telah membuat Grand Strategi Pengembangan Pasar Perbankan Syariah. Ada 6 (enam) poin dalam grand desain tersebut yaitu: ${ }^{15}$

Pertama, menerapkan visi baru pengembangan perbankan syariah pada fase I tahun 2008 membangun pemahaman perbankan syariah sebagai Beyond Banking, dengan pencapaian target asset sebesar Rp50 triliun dan pertumbuhan industri sebesar 40\%, fase II tahun 2009 menjadikan perbankan syariah Indonesia sebagai perbankan syariah paling atraktif di ASEAN dengan pencapaian target asset sebesar 87 triliun dan pertumbuhan industri sebesar 75\%. Fase III tahun 2010 menjadikan perbankan syariah Indonesia sebagai perbankan syariah terkemuka di ASEAN, dengan pencapaian target asset sebesar Rp 124 triliun dan pertumbuhan industri sebesar 81\%.

Kedua, program pencitraan baru perbankan syariah yang meliputi aspek positioning, differentiation, dan branding. Positioning baru bank syariah sebagai perbankan yang saling menguntungkan kedua belah pihak, aspek diferensiasi dengan keunggulan kompetitif dengan produk dan skema yang beragam, transparans, kompeten dalam keuangan dan beretika, tekhnologi informasi yang selalu up-date dan user friendly, serta adanya ahli investasi keuangan syariah yang memadai. Sedangkan pada aspek branding adalah "bank syariah lebih dari sekedar bank atau beyond banking".

Ketiga, program pemetaan baru secara lebih akurat terhadap potensi pasar perbankan syariah yang secara umum mengarahkan pelayanan jasa bank syariah sebagai layanan universal atau bank bagi semua lapisan masyarakat dan semua segmen dengan strategi masing-masing bank syariah.

Keempat, program pengembangan produk yang diarahkan kepada variasi produk yang bergam didukung oleh keunikan value yang ditawarkan dan dukungan jaringan kantor yang luas dan penggunaan standar nama produk yang mudah dipahami.

Kelima, program peningkatan kualitas layanan yang didukung oleh SDM yang kompeten dan peyediaan teknologi informasi yang mampu memenuhi kebutuhan dan kepuasan nasabah serta mampu mengkomunikasikan produk dan jasa bank syariah kepada nasabah secara benar dan jelas, dengan tetap memenuhi prinsip syariah.

Keenam, program sosialisasi dan edukasi masyarakat secara lebih luas dan efisien melalui berbagai sarana komunikasi langsung maupun tidak langsung yang bertujuan untuk memberikan pemahaman tentang kemanfaatan produk serta jasa perbankan syariah yang dapat dimanfaatkan oleh masyarakat.

13 Bank Indonesia, "Sekilas Perbankan Syariah di Indonesia” http://www.bi.go.id/web/id/Perbankan/Syariah/ Contents/default.aspx. diakses pada 2 Januari 2017.

14 Wiroso, 2011, Akuntansi Transaksi Syariah, Jakarta: Ikatan Akuntan Indonesia, h-18-19

15 Bank Indonesia, "Sekilas Perbankan Syariah di Indonesia" http://www.bi.go.id/web/id/Perbankan/Syariah/ Contents/default.aspx. diakses pada 2 Januari 2017. 
c. Penerapan Akuntansi Syariah

Penerapan dari PSAK mengenai akuntansi syariah yaitu PSAK 101 sampai dengan PSAK 107 dipergunakan secara umum oleh seluruh entitas yang melaksanakan transaksi syariah, seperti Bank syariah, Asuransi syariah, Lembaga Pembiayaan syariah, Koperasi syariah dan sejenisnya termasuk pihak-pihak yang terkait. Disisi lain terdapat PSAK yang hanya dipergunakan oleh industri khusus, karena memiliki karakter khusus yang tidak dapat disamakan dengan entitas yang lain misalnya asuransi syariah, oleh karena itu dalam melaksanakannya industri khusus ini harus menerapkan PSAK yang berlaku umum dan juga PSAK khusus tersebut. ${ }^{16}$

d. Dampak dari Peraturan dan Penerapan Akuntansi Syariah

Dampak peraturan dan penerapan akuntansi syariah pada saat sekarang ini lebih menunjukkan pada perkembangan ilmu pengetahuan mengenai syariah dan perbaikan dalam sistem akuntansi syariah di Indonesia. Selain itu akuntansi syariah juga telah memiliki peraturan dan dasar untuk menunjang pengaplikasiannya.

\section{KESIMPULAN}

Beberapa tahapan dalam perkembangan peraturan dan penerapan akuntansi syariah di Indonesia menunjukkan adanya perkembangan. Pada awal Indonesia baru saja merintis munculnya ekonomi syariah dan sistem akuntansi syariah. Pada tahap pertengahan sudah mulai adanya peraturan yang khusus diperumtukkan bagi perbankan syariah karena kemunculan ekonomi syariah pertama kali dipraktekkan oleh Lembaga keuangan bank maka wajar pemerintah lebih memfokuskan peraturan bagi perbankan syariah. Pada masa sekarang sudah adanya perundangan yang mengatur ekonomi syariah dan akuntansi syariah juga sudah memiliki panduan dalam pengaplikasiannya. Memang pada kenyataanya pengaplikasian akuntansi syariah masih belum sempurna hal ini dapat dilihat dari pengamatan, pertama terkait peraturan terhadap jam sholat bagi pegawai di semua perbankan syariah seharusnya ditegaskan agar tepat waktu seperti Bank BNI yang telah menerapkan hal tersebut. Kedua perbankan seharusnya melakukan pengkajian lebih dalam mengenai akad-akad yang bisa digunakan dalam perbankan syariah agar akad salam, istishna dan akad yang belum diterapkan dalam perbankan dapat diaplikasikan. Ketiga dukungan yang intensif dari pemerintah agar perkembangan sistem ekonomi dan akuntansi syariah bisa lebih berkembang.

\section{DAFTAR PUSTAKA}

Al quranul qarim

Bank Indonesia, "Sekilas Perbankan Syariah di Indonesia” http://www.bi.go.id/web/id/Perbankan/ Syariah/Contents/default.aspx. diakses pada 2 Januari 2017.

Bank Indonesia, 2007, “Cetak Biru Pengembangan Perbankan Syariah Indonesia”, http://www. bi.go.id/id/publikasi/lain/lainnya/pages/blue\%20print.aspx, diunduh Febuari 2016

Himawati Susana dan Agung Subono .2009. Praktik Akuntansi Dan Perkembangan Akuntansi Syariah di Indonesia. Sosial Budaya, 2 (2). ISSN 1979-6889

Mar'a Elthaf Ilahiyah Pro Kontra Sistem Akuntansi Syariah Di Indonesia "Terkait Konvergensi IFRS Di Indonesia". Jurnal Universitas Negeri Surabaya

PT Bank Muamalat Indonesia tbk, “Tentang Muamalat”, http://www.bankmuamalat.co.id/profilbank-muamalat, diunduh Januari 2017

16 Wiroso, 2011, Akuntansi Transaksi Syariah, Jakarta : Ikatan Akuntan Indonesia, h-19 
Risa Septiani Dr. Imam Subaweh “Analisis Pengaruh Pemahaman Dan Penerapan Ekonomi Syariah Oleh Sumber Daya Insani Terhadap Profitabiltas Pada Lembaga Keuangan Syariah Di Wilayah Depok”. Jurnal Fakultas Ekonomi, Universitas Gunadarma

Sutiono, 2015, "Profil Perekonomian Indonesia" http://www.bppk.kemenkeu.go.id/publikasi/ artikel/150-artikel-keuangan-umum/21178-profil-perekonomian-indonesia

Syafei Ade Wirman, Sisca Debyola Widuhung, Kuncoro Hadi, 2013 Penerapan "Teknologi (Sistem) Berbasis Islam Pada Bank Syariah Di Indonesia”. Jurnal Al-Azhar Indonesia Seri Pranata Sosial, Vol . 2, No. 1, Maret

Wiroso, 2011, “Akuntansi Transaksi Syariah”, Jakarta: Ikatan Akuntan Indonesia 